University of Nebraska - Lincoln

DigitalCommons@University of Nebraska - Lincoln

Faculty Papers and Publications in Animal

Science

Animal Science Department

2009

\title{
Winter Grazing System and Supplementation During Late Gestation Influence Performance of Beef Cows and Steer Progeny
}

Daniel Larson

University of Nebraska-Lincoln

J. L. Martin

University of Nebraska-Lincoln

Don C. Adams

University of Nebraska-Lincoln, dadams1@unl.edu

Richard N. Funston

University of Nebraska-Lincoln, rfunston2@unl.edu

Follow this and additional works at: https://digitalcommons.unl.edu/animalscifacpub

Part of the Animal Sciences Commons

Larson, Daniel; Martin, J. L.; Adams, Don C.; and Funston, Richard N., "Winter Grazing System and Supplementation During Late Gestation Influence Performance of Beef Cows and Steer Progeny" (2009). Faculty Papers and Publications in Animal Science. 605.

https://digitalcommons.unl.edu/animalscifacpub/605

This Article is brought to you for free and open access by the Animal Science Department at DigitalCommons@University of Nebraska - Lincoln. It has been accepted for inclusion in Faculty Papers and Publications in Animal Science by an authorized administrator of DigitalCommons@University of Nebraska - Lincoln. 


\title{
Winter grazing system and supplementation during late gestation influence performance of beef cows and steer progeny ${ }^{1}$
}

\author{
D. M. Larson, J. L. Martin, D. C. Adams, and R. N. Funston ${ }^{2}$ \\ University of Nebraska West Central Research and Extension Center, North Platte 69101
}

\begin{abstract}
A $2 \times 2$ factorial study evaluated effects of cow wintering system and last trimester CP supplementation on performance of beef cows and steer progeny over a 3-yr period. Pregnant composite cows (Red Angus $\times$ Simmental) grazed winter range $(\mathrm{WR} ; \mathrm{n}$ $=4 / \mathrm{yr})$ or corn residue $(\mathrm{CR} ; \mathrm{n}=4 / \mathrm{yr})$ during winter and within grazing treatment received $0.45 \mathrm{~kg} / \mathrm{d}(\mathrm{DM})$ $28 \% \mathrm{CP}$ cubes (PS; $\mathrm{n}=4 / \mathrm{yr}$ ) or no supplement (NS; $\mathrm{n}$ $=4 / \mathrm{yr}$ ). Offspring steer calves entered the feedlot $14 \mathrm{~d}$ postweaning and were slaughtered $222 \mathrm{~d}$ later. Precalving BW was greater $(P=0.02)$ for PS than NS cows grazing WR, whereas precalving BCS was greater $(P<$ 0.001) for cows grazing CR compared with WR. Calf birth BW was greater $(P=0.02)$ for $\mathrm{CR}$ than $\mathrm{WR}$ and tended to be greater $(P=0.11)$ for PS than NS cows. Prebreeding BW and BCS were greater $(P \leq 0.001)$ for CR than WR cows and PS than NS $(P=0.006)$ cows. At weaning, CR cows were heavier $(P<0.001)$ than WR cows but had similar BCS $(P=0.74)$. Cow weaning BW and BCS were not affected $(P>0.32)$ by PS.
\end{abstract}

Calf weaning BW was less $(P=0.01)$ for calves from NS cows grazing WR compared with all other treatments. Pregnancy rate was unaffected by treatment $(P>0.39)$. Steer ADG, 12th-rib fat, yield grade, and LM area $(P>0.10)$ were similar among all treatments. However, final BW and $\mathrm{HCW}(P=0.02)$ were greater for steers from PS-WR than NS-WR cows. Compared with steers from NS cows, steers from PS cows had greater marbling scores $(P=0.004)$ and a greater $(P$ $=0.04$ ) proportion graded USDA Choice or greater. Protein supplementation of dams increased the value of calves at weaning $(P=0.03)$ and of steers at slaughter regardless of winter grazing treatment $(P=0.005)$. Calf birth and weaning BW were increased by grazing CR during the winter. Calf weaning BW was increased by PS of the dam if the dam grazed WR. Compared with steers from NS cows, steer progeny from PS cows had a greater quality grade with no $(P=0.26)$ effect on yield grade. These data support a late gestation dam nutrition effect on calf production via fetal programming.

Key words: carcass quality, crude protein supplement, fetal programming, maternal nutrition, reproduction

(C)2009 American Society of Animal Science. All rights reserved.

J. Anim. Sci. 2009. 87:1147-1155 doi:10.2527/jas.2008-1323

\section{INTRODUCTION}

Protein supplementation of spring calving beef cows grazing dormant Sandhills range during late gestation does not improve cow reproductive performance (Stalker et al., 2006) despite the fact that nutrient requirements are greater than nutrient content of the grazed forage (NRC, 1996). Supplementation increased progeny weaning BW and increased fertility of heifer progeny (Stalker et al., 2006; Martin et al., 2007). Corn crop

\footnotetext{
${ }^{1}$ A contribution of the University of Nebraska Agricultural Research Division, supported in part by funds provided through the Hatch Act. Mention of a trade name, proprietary products, or company name is for presentation clarity and does not imply endorsement by the authors or the University of Nebraska.

${ }^{2}$ Corresponding author: rfunston2@unl.edu

Received July 23, 2008.

Accepted October 30, 2008.
}

residue $(\mathbf{C R})$ remaining after grain harvest provided a winter grazing alternative more economical than feeding harvested forage (Adams et al., 1996). Further, CR grazing reduced breakeven costs of weaned calves or finished steers compared with systems relying on winter grazing of dormant cool-season pasture supplemented with harvested forage (Anderson et al., 2005).

The fetal programming hypothesis states postnatal growth and physiology can be influenced by stimulus experienced in utero (Barker et al., 1993). Previous research (Stalker et al., 2006; Martin et al., 2007) utilizing the same cowherd used in the current study provided evidence for fetal programming of reproductive tissue and endocrine metabolism of progeny from cows grazing dormant winter range without supplementation. There is potential for maternal nutrition to affect not only cow productivity but also postweaning steer calf productivity. The objectives of the current study were to determine the effects of grazing dormant Sandhills winter range or corn crop residue with or without 
$\mathrm{CP}$ supplementation on performance of cows and their steer progeny.

\section{MATERIALS AND METHODS}

The University of Nebraska-Lincoln Institutional Animal Care and Use Committee approved all procedures and facilities used in this experiment.

\section{Cow and Calf Management}

A 3-yr study utilized composite Red Angus $\times$ Simmental cows and their progeny at Gudmundsen Sandhills Laboratory (GSL), Whitman, NE (preweaning data collection) and West Central Research and Extension Center, North Platte, NE (postweaning data collection). Cows were used in a completely randomized design with a $2 \times 2$ factorial arrangement of treatments to determine effects of grazing dormant Sandhills winter range (WR) or $\mathrm{CR}$ and receiving $\mathrm{CP}$ supplement (PS) or no supplement (NS) on cow and progeny performance. One hundred nine pregnant, spring-calving cows (498 $\pm 15 \mathrm{~kg}$ initial BW) between 3 and $5 \mathrm{yr}$ of age were stratified by age and weaning BW of their previous calf and assigned randomly to treatment in yr 1. Cows remained on the same treatment for the length of the study, unless removed due to reproductive failure or injury. Pregnant 3-yr-old cows were stratified by age and weaning BW of their previous calf and assigned randomly to treatment to replace cows removed from the study and to increase numbers as forage availability allowed. Data are reported for 2005 (109 cows), 2006 (114 cows), and 2007 (116 cows).

The nutrient concentrations for the various feedstuffs consumed by cows are presented in Table 1 . Dietary nutrient composition was estimated from masticate samples obtained from 3 esophageally fistulated cows per field. Cows were withheld from feed for $12 \mathrm{~h}$, then fitted with screen bottom bags after removal of the esophageal plug. Cows were allowed to graze for about $30 \mathrm{~min}$ to obtain samples. Masticate samples were freeze-dried and analyzed for CP (AOAC 990.03, 1990), NDF (Van Soest et al., 1991), and ADF (AOAC 973.18, 1990). Supplement nutrient composition, including UIP concentration of the feedstuffs, was calculated from tabular values (NRC, 1996). From late November until early March each year, cows grazing winter range were divided into four 32-ha upland pastures; 2 pastures received PS, 2 did not. Upland range sites at GSL are dominated by little bluestem [Andropogon scoparius (Michx.) Nash], prairie sandreed [Calamovilfa longifolia (Hook.) Scribn.], sand bluestem (Andropogon hallii Hack.), sand lovegrass [Eragrostis trichoides (Nutt.) Wood], and blue grama [Bouteloua gracillis (H.K.B.) Lag. Ex Griffiths] (Adams et al., 1998). From November to March each year, cows grazing CR were maintained in 4 fields; 2 fields received PS, 2 did not. Cows were shipped approximately $84 \mathrm{~km}$ to corn residue fields on November 15th and returned to GSL on February 25th the fol-
Table 1. Nutrient analysis of corn residue, winter range, and CP supplement consumed by beef cows during the last trimester of gestation

\begin{tabular}{lcccc}
\hline \hline & \multicolumn{4}{c}{$\mathrm{DM}, \%$} \\
\cline { 2 - 5 } Item & $\mathrm{CP}$ & $\mathrm{UIP}, \%$ CP & ADF & TDN \\
\hline Corn residue & 5.2 & - & 49.3 & 52.7 \\
Upland range $_{\text {Supplement }}{ }^{1}$ & 6.8 & - & 42.8 & 54.4 \\
\hline
\end{tabular}

${ }^{1} \mathrm{DM}$ basis; $62 \%$ dried distillers grain plus solubles, $11 \%$ wheat middlings, cottonseed meal 9\%, DCGF $5 \%$, molasses $5 \%$, urea $2 \%$, vitamin and trace mineral package $6 \%, 80 \mathrm{mg} \cdot$ animal $^{-1} \cdot \mathrm{d}^{-1}$ of Rumensin (Elanco Animal Health, Indianapolis, IN).

lowing year. The corn fields were irrigated, planted in April, and harvested in October, with an average annual yield of $12,544 \mathrm{~kg} / \mathrm{ha}$. On a pasture or field basis, cows received the equivalent of $0.45 \mathrm{~kg} / \mathrm{d}$ of a $28 \% \mathrm{CP}$ (DM basis) supplement 3 times/wk or no CP supplement from December 1 until February 28 on WR or until February 25th on CR. The supplement contained $62.0 \%$ dried distillers grains plus solubles, $10.6 \%$ wheat middlings, $9.0 \%$ cottonseed meal, $5.0 \%$ dried corn gluten feed, $5.0 \%$ molasses, $3.0 \%$ calcium carbonate, and $2.0 \%$ urea on a DM basis (Table 1). Additionally, the supplement was formulated to meet vitamin and trace mineral requirements of the 3 -yr-old cows and supply $80 \mathrm{mg} \cdot \mathrm{animal}^{-1} \cdot \mathrm{d}^{-1}$ of monensin (Rumensin, Elanco Animal Health, Indianapolis, IN).

After winter grazing, cows were managed in a common group and fed cool-season grass hay harvested from subirrigated meadows and a $\mathrm{CP}$ supplement. At the beginning of the calving season (March 1 to April 20), cows were vaccinated against Clostridium perfringens C/Escherichia coli/Rotavirus/Coronavirus [Scour Bos 9, Novartis Animal Health, Bucyrus, KS, and Scour Guard $3(\mathrm{~K}) / \mathrm{C}$, Pfizer Animal Health, Exton, PA]. The average calving date was March 26. Cows returned to upland range in late May and remained in a common group throughout the breeding season until the subsequent winter grazing period. At the beginning of the breeding season (June 5), cows received an infectious bovine rhinotracheitis/parainfluenza-3 virus/bovine respiratory syncytial virus/bovine viral diarrhea (killed)/ Leptospirosis/Vibriosis (Vira Shield 4+VL5, Novartis Animal Health) vaccination. Cows were exposed to fertile bulls at a ratio of approximately 1:25 for $60 \mathrm{~d}$ each year, beginning on June 5 and ending August 8. At branding in the first week of May, all bull calves were castrated and all calves given a Mannheimia (Pasteurella) hemolytica type A1 vaccination (One Shot, Pfizer Animal Health) and a 7-way clostridial (Vision 7, Intervet, Millsboro, DE) vaccination.

Precalving, prebreeding, and weaning BW and BCS (Wagner et al., 1988) were recorded each year. Cows were not limit fed before weighing. A subset of cows (n $=12$ to 15 per treatment) were assigned randomly to 1 of 4 weigh-suckle-weigh groups (Boggs et al., 1980). 
Table 2. Composition of backgrounding and finishing diets fed in the feedlot to steer progeny of cows that grazed winter range or corn residue with or without a CP supplement during the last trimester of gestation

\begin{tabular}{lcc}
\hline \hline & \multicolumn{2}{c}{ DM, \% } \\
\cline { 2 - 3 } Item & Backgrounding $^{1}$ & Finishing $^{2}$ \\
\hline Dry rolled corn & 15 & 48 \\
Wet corn gluten feed & 40 & 40 \\
Alfalfa hay & 35 & 7 \\
Supplement & $10^{3}$ & $5^{3}$ \\
\hline
\end{tabular}

${ }^{1}$ Contained $20 \% \mathrm{CP}, 1.1 \% \mathrm{Ca}, 0.58 \% \mathrm{P}$, and $1.2 \% \mathrm{~K}$ (DM basis).

${ }^{2}$ Contained $16 \% \mathrm{CP}, 0.67 \% \mathrm{Ca}, 0.56 \% \mathrm{P}$, and $0.9 \% \mathrm{~K}$ (DM basis).

${ }^{3}$ Provided dietary concentration of $28 \mathrm{~g} / \mathrm{t}$ of monensin and $10 \mathrm{~g} / \mathrm{t}$ of tylosin (DM basis, Elanco Animal Health, Indianapolis, IN).

Four groups were used to reduce variation in time between nursing and calf BW, providing a more accurate measure of milk production. Milk production data were collected each year in late May, before the grazing season, and at weaning. Pregnancy was diagnosed via rectal palpation or transrectal ultrasonography $60 \pm 1$ $\mathrm{d}$ following the end of the breeding season.

\section{Steer Calf Management}

Steer (yr $1=51$ steers; yr $2=58$ steers, yr $3=$ 63 steers) treatments included only dam winter grazing system and late gestation CP supplementation; no further treatments were applied to calves. Before and at weaning, steers received 2 doses of an infectious bovine rhinotracheitis/parainfluenza-3 virus/bovine respiratory syncytial virus/bovine viral diarrhea vaccine (PRISM 4, Ft. Dodge Animal Health, Overland Park, KS) $14 \mathrm{~d}$ apart. Approximately $14 \mathrm{~d}$ following weaning, calves were transported to the West Central Research and Extension Center, North Platte, NE. After arrival, steers were limit fed a starter diet containing $35 \%$ ground alfalfa hay, $40 \%$ wet corn gluten feed, $17.5 \%$ dry rolled corn, and $7.5 \%$ supplement at $2.0 \%$ of BW (DM basis; Table 2) for $5 \mathrm{~d}$.

Initial BW was calculated from BW taken on 2 consecutive days. At this time, steers were administered an initial implant containing $20 \mathrm{mg}$ of estradiol benzoate and $200 \mathrm{mg}$ of progesterone (Synovex S, Ft. Dodge Animal Health) and received moxidectin (Cydectin, Ft. Dodge Animal Health). Steers were assigned to pen $\times$ dam treatment (approximately 7 steers/pen; 2 pens $^{-1}$.treatment ${ }^{-1} \cdot \mathrm{yr}^{-1}$ ), fed in concrete fence-line bunks once daily, and had access to an automatic water supply. Steers were adapted over $21 \mathrm{~d}$ to a finishing diet (DM basis; Table 2), which included $48 \%$ dry rolled corn, $40 \%$ wet corn gluten feed, $7 \%$ ground alfalfa hay, and 5\% supplement. Approximately $100 \mathrm{~d}$ before the estimated slaughter date, steers were implanted with 24 $\mathrm{mg}$ estradiol and $120 \mathrm{mg}$ trenbolone acetate (Revelor $\mathrm{S}$, Intervet). Steers were slaughtered when estimated visually to have $1.3-\mathrm{cm}$ fat thickness over the 12 th rib.
Steers were slaughtered at a commercial abattoir, and routine carcass data were collected after a 24-h chill. Final BW was calculated from $\mathrm{HCW}$ using a common dressing percentage (63\%) and $4 \%$ shrink to account for transport BW loss. Percentage empty body fat (EBF) was calculated using the formula developed by Guiroy et al. (2001), which is $17.76107+(11.8908 \times 12$ th-rib fat depth $)+(0.0088 \times \mathrm{HCW})+(0.81855 \times[$ (marbling score $/ 100)+1)]-(0.4356 \times$ LM area $)$.

\section{Economic Analysis}

Partial budgeting was utilized to determine the effect of winter system and CP supplementation on profitability of the beef cow enterprise. Actual purchase price as delivered to the ranch plus a delivery charge $(\$ 0.07 / \mathrm{kg})$ were used to determine CP supplement cost $\left(\$ 31.89 \cdot \mathrm{cow}^{-1} \cdot \mathrm{yr}^{-1}\right)$. Corn residue grazing costs were collected from survey data of the grazing region in $\mathrm{Ne}-$ braska, and the cost of trucking to corn residue was added to the total grazing cost $\left(\$ 66.66 \cdot \mathrm{cow}^{-1} \cdot \mathrm{yr}^{-1}\right)$. Cost of grazing winter range was considered to be two-thirds the value of grazing the same area in the summer averaged across year $\left(\$ 65.27 \cdot \mathrm{cow}^{-1} \cdot \mathrm{yr}^{-1}\right)$. This value was calculated using reported and measured values of $\mathrm{CP}$ in winter and summer range for the area and the study site. The $\mathrm{CP}$ concentration of winter range is approximately two-thirds the $\mathrm{CP}$ concentration of summer range. The sale values of the steers at weaning were those reported by USDA Agricultural Marketing Service for each individual sale (USDA-AMS, 2008a). The cow feed costs were used to calculate the input cost and were subtracted from the value of the weaned calf, including steers and heifers, to arrive at a net return for the cow/calf enterprise.

Corn and hay prices for finishing steers were averaged for the feeding period within each year from Nebraska state average monthly prices. Wet corn gluten feed was valued at $90 \%$ the value of corn on a DM basis, and actual purchase price was used for supplement cost in the finishing ration. The average feedlot ration cost was $\$ 0.14 / \mathrm{kg}$. All nonfeeding costs, including veterinary charges, implant cost, trucking, and yardage were charged at an additional $\$ 0.50 / \mathrm{d}$. The sale value of steers at slaughter was calculated from the average carcass base price and grid adjustments reported by USDA Agricultural Marketing Service for each individual slaughter date (USDA-AMS, 2008b,c). These prices were used to calculate the total cost of feeding and were added to the cost of the steer calf at weaning to arrive at a total feedlot cost. The total feeding cost was subtracted from the value of the carcass on a grid basis to arrive at a feedlot profit, related to dam winter system and $\mathrm{CP}$ supplementation.

\section{Statistical Analysis}

As treatments were applied on a field basis, winter pasture $(\mathrm{n}=4 / \mathrm{yr})$ or corn residue field $(\mathrm{n}=4 / \mathrm{yr})$ was 
Table 3. Effects of grazing winter range or corn residue and CP supplementation during the last trimester of gestation on cow performance and reproduction

\begin{tabular}{|c|c|c|c|c|c|c|c|c|}
\hline \multirow{2}{*}{ Trait } & \multicolumn{4}{|c|}{ Treatment $^{1}$} & \multirow{2}{*}{ SEM } & \multirow{2}{*}{\multicolumn{3}{|c|}{ Treatment $P$-value ${ }^{2}$}} \\
\hline & \multicolumn{2}{|c|}{ WR } & \multicolumn{2}{|c|}{$\mathrm{CR}$} & & & & \\
\hline $\mathrm{n}$ & 6 & 6 & 6 & 6 & - & - & - & - \\
\hline Precalving BW, kg & $518^{\mathrm{a}}$ & $480^{\mathrm{b}}$ & $546^{\mathrm{c}}$ & $537^{\mathrm{c}}$ & 16 & $<0.001$ & $<0.001$ & 0.02 \\
\hline Calved in the first $21 \mathrm{~d}, \%$ & $83^{\mathrm{a}}$ & $62^{\mathrm{b}}$ & $78^{\mathrm{a}}$ & $80^{\mathrm{a}}$ & 5 & 0.20 & 0.07 & 0.03 \\
\hline Prebreeding BW, $\mathrm{kg}$ & 468 & 453 & 494 & 488 & 22 & $<0.001$ & 0.006 & 0.16 \\
\hline Prebreeding BCS & 5.28 & 5.02 & 5.41 & 5.27 & 0.06 & 0.004 & 0.003 & 0.32 \\
\hline May 24 -h milk, kg & 5.5 & 5.4 & 6.1 & 5.7 & 0.9 & 0.08 & 0.39 & 0.48 \\
\hline Nov. 24 -hr milk, kg & 2.3 & 2.5 & 3.5 & 3.5 & 0.3 & 0.002 & 0.85 & 0.67 \\
\hline Cow weaning BW, $\mathrm{kg}$ & $496^{\mathrm{a}}$ & $482^{\mathrm{b}}$ & $508^{\mathrm{c}}$ & $516^{\mathrm{c}}$ & 14 & $<0.001$ & 0.32 & 0.006 \\
\hline
\end{tabular}

${ }^{\mathrm{a}-\mathrm{c}}$ Within a row, means without a common superscript differ at $P<0.05$.

${ }^{1}$ WR-PS = dams supplemented 3 times per week with the equivalent of $0.45 \mathrm{~kg} / \mathrm{d}$ of $28 \% \mathrm{CP}$ cake (DM basis) during gestation and grazed dormant winter range; WR-NS = dams not supplemented with CP during gestation, grazed dormant winter range; CR-PS = dams supplemented with the equivalent of $0.45 \mathrm{~kg} / \mathrm{d} 28 \% \mathrm{CP}$ cake (DM basis) during gestation and grazed corn residue between weaning and the subsequent calving season; CR-NS = dams not supplemented with CP during gestation, grazed corn residue between weaning and the subsequent calving season.

${ }^{2}$ Sys $=$ winter grazing system treatment main effect; Supp $=\mathrm{CP}$ supplementation treatment main effect; $\mathrm{S} \times \mathrm{S}=$ winter grazing system $\times \mathrm{CP}$ supplementation treatment interaction.

considered the experimental unit for the cow performance and reproductive data. In addition, $\mathrm{CP}$ was or was not provided to 2 winter pastures and 2 corn residue fields per year $\left(\mathrm{n}=4 \cdot \mathrm{CP}\right.$ treatment $\left.{ }^{-1} \cdot \mathrm{yr}^{-1}\right)$. Pen was considered the experimental unit for the steer performance and carcass data because steers were penned by dam treatment group. Each interactive treatment was replicated twice each year, for an $\mathrm{n}$ of 6 per treatment total. Means for biological and economic data were calculated for each individual field or pasture unit and analyzed on a unit basis. Data were analyzed using PROC MIXED (SAS Inst. Inc., Cary, NC). The statistical model included winter grazing system, CP supplementation, and the interaction. Cow age was included as a covariate for cow performance traits and calf data collected until weaning, where it represented a significant $(P \leq 0.15)$ source of variation. Year was included as a random variable in all analyses.

\section{RESULTS AND DISCUSSION}

\section{Cow Performance and Calf Production}

The data describing the effect of winter grazing and late gestation $\mathrm{CP}$ supplementation on cow production are presented in Table 3. For variables where the interactive effect of winter grazing and PS is significant $(P \leq 0.05)$, with the exceptions of precalving BCS and carcass value, the difference between the interaction of CR-PS and CR-NS is not different $(P>0.05)$. Thus, only the difference between WR-PS and WR-NS will be discussed hereafter. Cow BW and BCS after the winter grazing period and before parturition were affected by the winter grazing system and $\mathrm{CP}$ supplementation.
Cows grazing CR between November and March were $42 \mathrm{~kg}$ heavier $(P<0.001)$ than counterparts grazing WR. In addition, cows receiving PS during late gestation, from December until March, were $23 \mathrm{~kg}$ heavier $(P$ $<0.001)$ than NS cows. In particular, cows grazing WR with NS were $37 \mathrm{~kg}$ lighter $(P=0.02)$ and had BCS approximately 0.37 points less $(P=0.10)$ than similarly grazed cows receiving PS. These results are similar to Stalker et al. (2006), who reported cows grazing winter range lost $29 \mathrm{~kg}$ and $0.6 \mathrm{BCS}$ if not PS, but maintained both if they received $0.45 \mathrm{~kg} / \mathrm{d}$ of $42 \% \mathrm{CP}$ supplement during this period. Calving date was nearly $5 \mathrm{~d}$ later $(P=0.01)$ for NS cows grazing WR compared with all other treatments. This is in contrast to Stalker et al. (2006), who found cows supplemented in late gestation calved later than nonsupplemented cows. However, in that study, cows did not remain on the same treatment for all $3 \mathrm{yr}$ of the study; rather a switchback design was utilized. Thus, because calving date is delayed in the current experiment where cows remained on the same treatment for $3 \mathrm{yr}$, it may represent a cumulative carryover effect of continued nutritional stress. There were also at least $16 \%$ fewer $(P=0.03)$ WR-NS cows that calved in the first $21 \mathrm{~d}$ compared with all other treatments, reinforcing the increase in calf birth date. Perhaps this is a reflection of differences in conception date, which would indicate WR-NS conceived later in the breeding season.

Prebreeding cow BW and BCS were increased $(P \leq$ $0.01)$ by winter grazing of $\mathrm{CR}$ and by PS. The interaction of grazing system and PS on prebreeding cow $\mathrm{BW}$ and BCS was no longer significant $(P \geq 0.16)$, but groups ranked nearly the same as they had before calving. Milk production of cows grazed on CR 
Table 4. Effects of grazing winter range or corn residue and $\mathrm{CP}$ supplementation during the last trimester of gestation on calf performance

\begin{tabular}{|c|c|c|c|c|c|c|c|c|}
\hline \multirow{2}{*}{ Trait } & \multicolumn{4}{|c|}{ Treatment $^{1}$} & \multirow{2}{*}{ SEM } & \multirow{2}{*}{\multicolumn{3}{|c|}{ Treatment $P$-value ${ }^{2}$}} \\
\hline & \multicolumn{2}{|c|}{ WR } & \multicolumn{2}{|c|}{$\mathrm{CR}$} & & & & \\
\hline $\mathrm{n}$ & 6 & 6 & 6 & 6 & - & - & - & - \\
\hline Calf birth BW, kg & 36.4 & 35.3 & 37.4 & 36.9 & 0.5 & 0.02 & 0.11 & 0.50 \\
\hline Weaned, \% & 100 & 98 & 98 & 99 & 1 & 0.68 & 0.59 & 0.16 \\
\hline Calf weaning BW, $\mathrm{kg}$ & $238^{\mathrm{a}}$ & $222^{\mathrm{b}}$ & $237^{\mathrm{a}}$ & $238^{\mathrm{a}}$ & 5 & 0.02 & 0.02 & 0.01 \\
\hline Calf $205-\mathrm{d}$ BW, kg & 223 & 214 & 224 & 224 & 4 & 0.04 & 0.07 & 0.11 \\
\hline
\end{tabular}

${ }^{\mathrm{a}, \mathrm{b}}$ Within a row, means without a common superscript differ at $P<0.05$.

${ }^{1}$ WR-PS = dams supplemented 3 times per wk with the equivalent of $0.45 \mathrm{~kg} / \mathrm{d} 28 \% \mathrm{CP}$ cake (DM basis) during gestation and grazed dormant winter range; WR-NS = dams not supplemented with $\mathrm{CP}$ during gestation, grazed dormant winter range; CR-PS = dams supplemented with the equivalent of $0.45 \mathrm{~kg} / \mathrm{d} 28 \% \mathrm{CP}$ cake (DM basis) during gestation and grazed corn residue between weaning and the subsequent calving season; $\mathrm{CR}-\mathrm{NS}=$ dams not supplemented with CP during gestation, grazed corn residue between weaning and the subsequent calving season.

${ }^{2}$ Sys $=$ winter grazing system treatment main effect; Supp $=\mathrm{CP}$ supplementation treatment main effect; $\mathrm{S} \times \mathrm{S}=$ winter grazing system by CP supplementation treatment interaction.

${ }^{3}$ Percentage treated for respiratory and gastrointestinal disease between birth and weaning.

tended $(P=0.08)$ to be greater than cows grazed on WR when measured in May. Milk production continued to be greater $(P=0.002)$ in November for cows that previously grazed CR. Corah et al. (1975) indicated 3 -yr-old cows offered a greater energy diet during late gestation had greater milk production than their counterparts offered a low energy diet. Protein supplementation did not affect $(P \geq 0.39)$ milk production in the spring or the fall. Cow BW and BCS at weaning were not affected $(P>0.32)$ by the main effect of PS, but cows grazing $\mathrm{CR}$ the previous winter were heavier $(P<$ $0.001)$ than WR at weaning despite similar $(P=0.74)$ BCS. Pregnancy rate was not affected $(P>0.39)$ by PS or winter grazing system. Stalker et al. (2006) also reported no benefit of PS on winter range on subsequent pregnancy rates.

Preweaning calf data are presented in Table 4. Calf birth BW was greater $(P=0.02)$ if their dams grazed CR than WR, and tended to increase $(P=0.11)$ with PS. This is somewhat surprising because previous research using the same cowherd did not find differences in calf birth BW due to supplementation of dams grazing winter range (Stalker et al., 2006; Martin et al., 2007). Once again, this may be a cumulative effect of remaining on the NS treatment. The differences, although significant, are rather small in the current study. In an earlier study, heifers offered a high energy ration 100 $\mathrm{d}$ before calving gave birth to heavier calves than heifers offered a low energy diet (Corah et al., 1975). Additionally, increasing BCS before parturition has been demonstrated to increase calf birth BW (Spitzer et al., 1995; Stalker et al., 2007). The increase in prepartum BCS demonstrated in this study and by Stalker et al. (2007) resulted from CP supplementation during late gestation. This provides evidence supplemental nutrition, including energy or $\mathrm{CP}$, during late gestation can increase cow BCS and calf birth BW. Calf BW in May was increased $(P<0.001)$ by $\mathrm{CP}$ supplementation if cows grazed WR but not CR. This may indicate a differential effect of $\mathrm{CP}$ on fetal programming of nutrientrestricted dams, resulting in efficiency differences of the calf as we demonstrate no effect of PS on May milk production.

In contrast with Stalker et al. (2006), there was no difference $(P \geq 0.16)$ in percentage of live calves weaned between winter grazing or CP supplementation systems in the current experiment. At weaning, actual $(P=$ $0.02)$ and adjusted calf BW $(P=0.07)$ were greater for calves from PS dams compared with calves from NS cows. This effect was most evident if the dam had grazed WR $(P=0.01)$. The weaning BW difference mirrors the improvement observed in May calf BW between the same groups. Additionally, cows grazing CR during the previous winter period weaned heavier $(P=$ 0.02 ) calves than cows grazing WR. This is likely due to the greater apparent milk production of CR dams. Similar effects of dam supplementation during winter grazing on calf weaning BW were reported in previous studies, although milk production was not measured in these experiments (Stalker et al., 2006; Martin et al., 2007). The percentage of calves treated for illness between birth and weaning was unaffected $(P>0.17)$ by winter grazing system or CP supplementation. Stalker et al. (2006) indicated no difference in serum IgG concentration between calves from PS and NS cows.

\section{Steer Production}

Steer growth performance is presented in Table 5 . Male calves from dams grazing WR with NS were born $10 \mathrm{~d}$ later $(P<0.001)$ than calves from dams grazing WR with PS. However, PS had an opposite effect if the dam grazed CR, where PS cows gave birth to calves 10 d later than NS cows $(P<0.001)$. Protein supplement- 
Table 5. Effects of dam winter grazing system and CP supplementation during the last trimester of gestation on performance of steer progeny

\begin{tabular}{|c|c|c|c|c|c|c|c|c|}
\hline \multirow{2}{*}{ Trait } & \multicolumn{4}{|c|}{ Treatment $^{1}$} & \multirow{2}{*}{ SEM } & \multirow{2}{*}{\multicolumn{3}{|c|}{ Treatment $P$-value ${ }^{2}$}} \\
\hline & \multicolumn{2}{|c|}{ WR } & \multicolumn{2}{|c|}{$\mathrm{CR}$} & & & & \\
\hline $\mathrm{n}$ & 6 & 6 & 6 & 6 & - & - & - & - \\
\hline Calf birth date, Julian d & $82^{\mathrm{a}}$ & $92^{\mathrm{b}}$ & $91^{\mathrm{b}}$ & $81^{\mathrm{a}}$ & 2 & 0.61 & 0.80 & $<0.001$ \\
\hline Calf adj. 205-d BW, kg & 231 & 219 & 227 & 229 & 6 & 0.45 & 0.19 & 0.10 \\
\hline Initial feedlot BW, $\mathrm{kg}$ & $243^{\mathrm{a}}$ & $222^{\mathrm{b}}$ & $233^{\mathrm{ab}}$ & $244^{\mathrm{a}}$ & 11 & 0.26 & 0.31 & 0.004 \\
\hline Reimplant BW, kg & $456^{\mathrm{a}}$ & $422^{\mathrm{b}}$ & $440^{\mathrm{ab}}$ & $444^{\mathrm{ab}}$ & 11 & 0.68 & 0.04 & 0.01 \\
\hline $\mathrm{ADG}, \mathrm{kg} / \mathrm{d}$ & 1.71 & 1.66 & 1.69 & 1.66 & 0.05 & 0.85 & 0.09 & 0.65 \\
\hline Final BW, kg & $622^{\mathrm{a}}$ & $591^{\mathrm{b}}$ & $609^{\mathrm{ab}}$ & $614^{\mathrm{a}}$ & 13 & 0.52 & 0.10 & 0.02 \\
\hline Treated, birth to weaning, ${ }^{3} \%$ & 17 & 17 & 20 & 19 & 11 & 0.68 & 0.91 & 0.99 \\
\hline
\end{tabular}

${ }^{\mathrm{a}, \mathrm{b}}$ Within a row, means without a common superscript differ at $P<0.05$.

${ }^{1}$ WR-PS $=$ dams supplemented 3 times per week with the equivalent of $0.45 \mathrm{~kg} / \mathrm{d} 28 \% \mathrm{CP}$ cake (DM basis) during gestation and grazed dormant winter range; WR-NS = dams not supplemented with $\mathrm{CP}$ during gestation, grazed dormant winter range; CR-PS = dams supplemented with the equivalent of $0.45 \mathrm{~kg} / \mathrm{d} 28 \% \mathrm{CP}$ cake (DM basis) during gestation and grazed corn residue between weaning and the subsequent calving season; $\mathrm{CR}-\mathrm{NS}=$ dams not supplemented with CP during gestation, grazed corn residue between weaning and the subsequent calving season.

${ }^{2}$ Sys $=$ winter grazing system treatment main effect; Supp $=\mathrm{CP}$ supplementation treatment main effect; $\mathrm{S} \times \mathrm{S}=$ winter grazing system by CP supplementation treatment interaction.

${ }^{3}$ Percentage treated for respiratory and gastrointestinal disease between birth and weaning.

${ }^{4}$ Percentage treated for respiratory and gastrointestinal disease between weaning and slaughter.

ed dams tended to give birth to heavier $(P=0.06)$ male calves than NS cows. The weaning BW of steer calves from cows grazing WR with NS was less $(P=0.01)$ than steers from WR-PS cows, but adjusted weaning BW of the same groups only tended $(P=0.10)$ to be different. Perhaps, weaning BW differences occurred partially because of differences in calf age.

At the time of feedlot entry, steers from WR cows with NS were still lighter $(P=0.004)$ than steers from WR-PS cows. At reimplant, steers from PS dams were heavier $(P=0.04)$ than steers from NS dams, which was more pronounced in steers from WR dams $(P=$ 0.01). There was no $(P=0.85)$ effect of winter grazing system on overall ADG. However, steers from PS dams tended $(P=0.09)$ to have a greater ADG than steers from NS dams. There was also a tendency $(P=0.07)$ for steers from PS dams to consume more feed on a pen basis during the finishing period. However, because ADG and DMI trended in a similar manner, there was no $(P>0.10)$ overall difference in BW gain efficiency. These data agree with Stalker et al. (2006) who found no difference in ADG or BW gain efficiency between calves from PS and NS dams. Steers born to cows grazing WR with NS were lighter $(P=0.02)$ than steers from WR-PS dams at slaughter. A similar trend existed for HCW (Table 6). Additionally, steers from cows receiving PS tended $(P=0.10)$ to have heavier HCW and final BW than steers from NS cows. This is similar to previous research demonstrating steers from PS dams produce heavier carcasses (Stalker et al., 2007) and steers from dams grazing improved pasture throughout gestation produced heavier carcasses than steers from dams grazing unimproved subtropical pastures (Greenwood et al., 2004).

Steer carcass data are presented in Table 6. External fat thickness measured over the 12th rib and LM area were similar $(P \geq 0.21)$ between winter grazing and PS systems. Calculated yield grade was likewise unaffected $(P=0.55)$ by winter system or PS $(P=0.26)$. Steers from PS cows tended to have a greater $(P=0.06)$ percentage of EBF compared with steers from NS cows. This is in contrast to Stalker et al. (2007) who found no effect of PS during late gestation on yield grade or EBF.

Interestingly, whereas marbling score was unaffected $(P=0.12)$ by winter system, steers from PS cows had greater $(P=0.004)$ marbling scores than steers from NS cows. The difference was nearly one-half of a grade and may represent an economically important change, as will be discussed further. Whereas there was only a tendency $(P=0.07)$ for a difference, steers from CR cows with NS had a decreased ratio of marbling per unit of yield grade, indicating they may be less valuable when marketed on a grid basis. Perhaps more importantly, a greater proportion $(P=0.04)$ of steers born to PS cows achieved USDA quality grades of Choice or greater. Notably, the magnitude of difference was only $8 \%$ if their dams grazed WR, but $23.6 \%$ if their dams grazed $\mathrm{CR}$ over the winter. In addition, more $(P=0.03)$ steers from PS dams graded USDA Modest or greater than steers from NS dams. Although dam grazing system did not affect $(P=0.57)$ quality grade, these data 
Table 6. Effects of dam winter grazing system and CP supplementation during the last trimester of gestation on carcass merit of steer progeny

\begin{tabular}{|c|c|c|c|c|c|c|c|c|}
\hline \multirow{2}{*}{ Trait } & \multicolumn{4}{|c|}{ Treatment $^{1}$} & \multirow{2}{*}{ SEM } & \multirow{2}{*}{\multicolumn{3}{|c|}{ Treatment $P$-value ${ }^{2}$}} \\
\hline & \multicolumn{2}{|c|}{ WR } & \multicolumn{2}{|c|}{$\mathrm{CR}$} & & & & \\
\hline $\mathrm{n}$ & 6 & 6 & 6 & 6 & - & - & - & - \\
\hline $\mathrm{HCW}, \mathrm{kg}$ & $376^{\mathrm{a}}$ & $357^{\mathrm{b}}$ & $368^{\mathrm{ab}}$ & $371^{\mathrm{a}}$ & 8 & 0.52 & 0.10 & 0.02 \\
\hline Empty body fat, $\%$ & 29.93 & 28.73 & 29.26 & 28.80 & 0.61 & 0.48 & 0.06 & 0.38 \\
\hline $\mathrm{LM}$ area, $\mathrm{cm}^{2}$ & 88.5 & 88.4 & 90.3 & 89.7 & 1.9 & 0.21 & 0.75 & 0.85 \\
\hline Yield grade & 2.94 & 2.69 & 2.74 & 2.77 & 0.18 & 0.55 & 0.26 & 0.16 \\
\hline Marbling:yield grade & 171.8 & 171.6 & 178.1 & 155.7 & 8.3 & 0.41 & 0.06 & 0.07 \\
\hline Quality grade, $\% \mathrm{Sm}^{4}$ or greater & 84.5 & 76.5 & 88.2 & 64.6 & 9.0 & 0.57 & 0.04 & 0.28 \\
\hline Quality grade, $\% \mathrm{Md}^{5}$ or greater & 43.2 & 26.6 & 35.4 & 15.0 & 1.0 & 0.34 & 0.03 & 0.81 \\
\hline
\end{tabular}

${ }^{\mathrm{a}, \mathrm{b}}$ Within a row, means without a common superscript differ at $P<0.05$.

${ }^{1}$ WR-PS $=$ dams supplemented 3 times per wk with the equivalent of $0.45 \mathrm{~kg} / \mathrm{d} 28 \% \mathrm{CP}$ cake (DM basis) during gestation and grazed dormant winter range; WR-NS = dams not supplemented with CP during gestation, grazed dormant winter range; CR-PS $=$ dams supplemented with the equivalent of $0.45 \mathrm{~kg} / \mathrm{d} 28 \% \mathrm{CP}$ cake (DM basis) during gestation and grazed corn residue between weaning and the subsequent calving season; $\mathrm{CR}-\mathrm{NS}=$ dams not supplemented with CP during gestation, grazed corn residue between weaning and the subsequent calving season.

${ }^{2}$ Sys $=$ winter grazing system treatment main effect; Supp $=\mathrm{CP}$ supplementation treatment main effect; $\mathrm{S} \times \mathrm{S}=$ winter grazing system $\times \mathrm{CP}$ supplementation treatment interaction.

${ }^{3}$ Where $400=$ small $^{0}$.

${ }^{4} \mathrm{Sm}=$ small quality grade, USDA low choice.

${ }^{5} \mathrm{Md}=$ modest quality grade, USDA average choice.

highlight a potential fetal programming effect of late gestation supplementation on subsequent steer progeny intramuscular fat deposition. Using only cows grazing WR, Stalker et al. (2006) were unable to identify any significant differences in steer progeny feedlot or carcass performance. However, they did note a tendency $(P=$ 0.16 ) for increased proportions of steers grading USDA Choice or greater if their dams were supplemented with CP during late gestation, with a comparable magnitude of difference achieved in the current study. The increase in percentage grading USDA Choice with PS, without a concomitant increase in yield grade, translated into a $\$ 47$ advantage $(P=0.005$; Table 7$)$ in carcass value over steers from NS cows.

As stated previously, fetal programming may explain the improvement in percentage USDA Choice with dam PS. Fetal growth progresses rapidly during the last trimester of gestation. Added nutrition during this period may alter the site of nutrient deposition. Early work by Smith and Crouse (1984) suggest glucose is the primary substrate utilized by intramuscular adipocytes. Furthermore, concentrate diets may increase the glucose uptake of intramuscular adipose cells (Rhoades et al., 2007). This is potentially due to increased insulin associated with concentrate feeding. Thus, under low quality range conditions when ruminants are increasingly insulin insensitive (Waterman et al., 2007), concentrate supplementation may increase insulin and subsequent glucose uptake of intramuscular adipocytes. Some data indicate a positive effect of a high concentrate diet early in life on quality grade at slaughter (Schoonmaker et al., 2003; Meyer et al., 2005). Feeding a high concentrate diet to early weaned steers in- creased serum insulin relative to high roughage diets (Schoonmaker et al., 2003). Grazing cows on improved pasture during late gestation increased the number of subcutaneous adipocytes in subsequent steer progeny relative to cows grazing native range (Underwood et al., 2008). Conversely, when ewes were nutritionally restricted during early gestation, adipose tissue volume was increased (Bispham et al., 2003). There appears to be a differential effect of maternal nutrition on fetal adiposity during various periods of gestation.

Added supply of glucogenic AA may have mediated the percentage of steers grading USDA Choice. Stalker et al. (2006) did not find a positive effect of CP supplementation on quality grade; however, the supplement used contained approximately $42 \%$ CP (31\% UIP) from predominately sunflower (50\%) and cottonseed (48\%) meals. The current study utilized a supplement containing $28 \%$ CP (48\% UIP) from predominately DDGS $(62 \%)$, wheat middlings (11\%), and cottonseed meal (9\%). Thus, increased UIP concentration may have changed AA supply and glucose production, affecting preadipocyte development and the propensity for developing intramuscular fat later in life. Increased CP in the ration has been shown to increase starch digestion and absorption in the small intestine along with increasing insulin concentration (Lopez et al., 2001). These data suggest a potential fetal programming effect of late-gestation cow supplementation on subsequent steer progeny intramuscular fat deposition.

An alternative hypothesis regarding PS effects on quality grade may involve treatment for postweaning illness. There was no effect $(P>0.68$; Table 5$)$ of winter grazing system on percentage of steers treated for 
Table 7. Costs and returns from d 180 of gestation to weaning and weaning until slaughter associated with dams grazing corn residue or winter range with or without CP supplement

\begin{tabular}{|c|c|c|c|c|c|c|c|c|}
\hline \multirow{2}{*}{ Item } & \multicolumn{4}{|c|}{ Treatment $^{1}$} & \multirow{2}{*}{ SEM } & \multirow{2}{*}{\multicolumn{3}{|c|}{ Treatment $P$-value ${ }^{2}$}} \\
\hline & \multicolumn{2}{|c|}{ WR } & \multicolumn{2}{|c|}{$\mathrm{CR}$} & & & & \\
\hline $\mathrm{n}$ & 6 & 6 & 6 & 6 & - & - & - & - \\
\hline \multicolumn{9}{|l|}{ Cow-calf phase } \\
\hline Protein supplement & 31.89 & - & 31.89 & - & - & - & - & - \\
\hline \multicolumn{9}{|l|}{ Returns, $\$ /$ calf } \\
\hline Weaned calf value ${ }^{3}$ & $645^{\mathrm{a}}$ & $611^{\mathrm{b}}$ & $645^{\mathrm{a}}$ & $647^{\mathrm{a}}$ & 24 & 0.02 & 0.03 & 0.01 \\
\hline Net return & $548^{\mathrm{a}}$ & $546^{\mathrm{a}}$ & $546^{\mathrm{a}}$ & $580^{\mathrm{b}}$ & 25 & 0.03 & 0.03 & 0.02 \\
\hline \multicolumn{9}{|l|}{ Feedlot phase } \\
\hline \multicolumn{9}{|l|}{ Input costs, $\$ /$ steer } \\
\hline
\end{tabular}

${ }^{\mathrm{a}, \mathrm{b}}$ Within a row, means without a common superscript differ at $P<0.05$.

${ }^{1}$ WR-PS $=$ dams supplemented 3 times per week with the equivalent of $0.45 \mathrm{~kg} / \mathrm{d} 28 \% \mathrm{CP}$ cake (DM basis) during gestation and grazed dormant winter range; WR-NS = dams not supplemented with CP during gestation, grazed dormant winter range; CR-PS = dams supplemented with the equivalent of $0.45 \mathrm{~kg} / \mathrm{d} 28 \% \mathrm{CP}$ cake (DM basis) during gestation and grazed corn residue between weaning and the subsequent calving season; $\mathrm{CR}-\mathrm{NS}=$ dams not supplemented with CP during gestation, grazed corn residue between weaning and the subsequent calving season.

${ }^{2} \mathrm{Sys}=$ winter grazing system treatment main effect; Supp $=\mathrm{CP}$ supplementation treatment main effect; $\mathrm{S} \times \mathrm{S}=$ winter grazing system $\times \mathrm{CP}$ supplementation treatment interaction.

${ }^{3}$ Value of all weaned calves, including steer and heifer calves.

${ }^{4}$ Value of steer calves only.

${ }^{5}$ Including yardage charged at $\$ 0.50 / \mathrm{d}$.

illness in any period. Furthermore, whereas PS did not affect $(P=0.91)$ health from birth until weaning, more $(P=0.05)$ calves from NS cows received treatment for bovine respiratory disease (BRD) between weaning and slaughter than steers from PS dams. Studies have demonstrated calves receiving treatment for BRD have decreased quality grades compared with steers not receiving treatment (Gardner et al., 1999; Busby et al., 2004). Busby et al. (2004) indicated one treatment reduced carcass quality (445 vs. 465 marbling score, treated and untreated, respectively; where $400=$ small ${ }^{0}$ ), and subsequent treatments reduced it further. Treating calves for BRD also increased the propensity for grading USDA Standard, and the presence of lung lesions at slaughter were associated with reduced quality grades (Gardner et al., 1999). In the current study, nearly $10 \%$ more steers $(P=0.05)$ from NS cows required treatment for BRD and PS improved marbling scores (444 vs. 492 marbling score, NS and PS, respectively; $P=0.004$ ). Thus, PS may have influenced quality grade through calf health. To our knowledge, this is the first report of maternal nutrition during late gestation influencing calf health after weaning without an effect on preweaning health.

\section{Economic Analysis}

The data for the economic analysis is presented in Table 7. If sold at weaning, calves from cows grazing
CR with NS $(P=0.02)$ returned $\$ 34$ to $\$ 36$ more per calf than calves from all other treatment groups. This is due in part to heavier weaning BW of CR-NS steers and the decreased cost associated with dam maintenance. The main effect of PS returned $\$ 16$ less $(P=$ 0.03 ) at weaning than NS, likely due to the cost of PS. In contrast to the entire calf crop, steers from WR-PS were valued at $\$ 48$ more $(P=0.009)$ per steer than steers from WR-NS, which is similar to Stalker et al. (2006) with dam PS increasing weaned steer value by $\$ 25.38$.

If steers were sold and fed in the feedlot, the carcasses of steers from PS were worth $\$ 47$ per steer more $(P=0.005)$ than steers from NS cows. This difference is the result of a $15 \%$ improvement in percentage grading USDA Choice for steers from PS cows. The main effect of PS also improved $(P=0.03)$ net feedlot return by nearly $\$ 30$ per steer relative to NS because of an increase in percentage USDA Choice carcasses and increased HCW. In contrast, Stalker et al. (2006) found essentially no difference in feedlot return $(\$ 0.65 /$ head $)$ for steers from PS or NS dams grazing WR.

\section{Concluding Remarks}

There appears to be fetal programming effects of winter grazing system and late gestation nutrition of the dam on the unborn fetus. Not only does nutrition of the dam affect calf birth BW and early BW gains, 
but this difference also persists through weaning and slaughter. This may indicate more than a transient change in physiology. It also appears maternal CP supplementation influences health of steer progeny in the feedlot. This hypothesis is further supported by an alteration in fatness and quality grade of steer progeny. It appears CP supplementation improves value of calves at weaning and the value of steers at slaughter regardless of winter grazing treatment. As rising input prices continue to affect cow/calf production, beef producers will turn to alternative feed sources. It is imperative to understand not only how these changes will affect the dam, but also what the lifelong effects may be on the calf.

\section{LITERATURE CITED}

Adams, D. C., R. T. Clark, T. J. Klopfenstein, and J. D. Volesky. 1996. Matching the cow with forage resources. Rangelands 18:57-62.

Adams, D. C., R. T. Clark, P. E. Reece, and J. D. Volesky. 1998. Research and education for managing resources within the Nebraska Sandhills: The Gudmundsen Sandhills Laboratory. Rangelands 20:4-8.

Anderson, R. V., R. J. Rasby, T. J. Klopfenstein, and R. T. Clark. 2005. An evaluation of production and economic efficiency of two beef systems from calving to harvest. J. Anim. Sci. 83:694-704.

AOAC. 1990. Official Methods of Analysis. 15th ed. Assoc. Off. Anal. Chem., Arlington, VA.

Barker, D. J. P., C. N. Martyn, C. Osmond, C. N. Hales, and C. H. D. Fall. 1993. Growth in utero and serum cholesterol concentration in adult life. BMJ 307:1524-1527.

Bispham, J., G. S. Gopalakrishanan, J. Dandrea, V. Wilson, H. Budge, D. H. Keisler, F. Broughton Pipkin, T. Stephenson, and M. E. Symonds. 2003. Maternal endocrine adaptation throughout pregnancy to nutritional manipulation: Consequences for maternal plasma leptin and cortisol and the programming of fetal adipose tissue development. Endocrinology 144:35753585 .

Boggs, D. L., E. F. Smith, R. R. Schalles, B. E. Brant, L. R. Corah, and R. J. Pruitt. 1980. Effects of milk and forage intake on calf performance. J. Anim. Sci. 51:550-553.

Busby, W. D., D. R. Stohbehn, P. Beedle, and L. R. Corah. 2004. Effect of postweaning health on feedlot performance and quality grade. A.S. Leaflet R1855. Iowa State Univ., Ames.

Corah, L. R., T. G. Dunn, and C. C. Kalthenbach. 1975. Influence of prepartum nutrition on the reproductive performance of beef females and the performance of their progeny. J. Anim. Sci. 41:819-824.

Gardner, B. A., H. G. Dolezal, L. K. Bryant, F. N. Owens, and R. A. Smith. 1999. Health of finishing steers: Effects on performance, carcass traits, and meat tenderness. J. Anim. Sci. $77: 3168-3175$.

Greenwood, P. L., H. Hearnshaw, L. M. Cafe, D. W. Hennessy, and G. S. Harper. 2004. Nutrition in utero and pre-weaning has longterm consequences for growth and size of Piedmontese and Wagyu-sired steers. J. Anim. Sci. 82(Suppl. 1.):722.

Guiroy, P. J., D. G. Fox, L. O. Tedeschi, M. J. Baker, and M. D. Cravey. 2001. Predicting individual feed requirements of cattle fed in groups. J. Anim. Sci. 79:1983-1995.

Lopez, R., C. R. Krehbiel, M. G. Thomas, D. M. Hallford, D. H. Keisler, B. S. Obeidat, J. A. Hernandez, W. D. Bryant, M.
Garcia, and R. Flores. 2001. Effect of increasing level dietary protein on serum concentrations of metabolic hormones and mammary development in Holstein heifers consuming a moderate-energy diet. J. Dairy Sci. 84(Suppl. 1):161.

Martin, J. L., K. A. Vonnahme, D. C. Adams, G. P. Lardy, and R. N. Funston. 2007. Effects of dam nutrition on growth and reproductive performance of heifer calves. J. Anim. Sci. 85:841847.

Meyer, D. L., M. S. Kerley, E. L. Walker, D. H. Keisler, V. L. Pierce, T. B. Schmidt, C. A. Stahl, M. L. Linville, and E. P. Berg. 2005. Growth rate, body composition, and meat tenderness in early vs. traditionally weaned beef calves. J. Anim. Sci. 83:2752-2761.

NRC. 1996. Nutrient Requirements of Beef Cattle. 7th ed. Natl. Acad. Press, Washington, DC.

Rhoades, R. D., J. E. Sawyer, K. Y. Chung, M. L. Schell, D. K. Lunt, and S. B. Smith. 2007. Effect of dietary energy source on in vitro substrate utilization and insulin sensitivity of muscle and adipose tissues of Angus and Wagyu steers. J. Anim. Sci. 85:1719-1726.

Schoonmaker, J. P., M. J. Cecava, D. B. Faulkner, F. L. Fluharty, H. N. Zerby, and S. C. Loerch. 2003. Effect of source of energy and rate of growth on performance, carcass characteristics, ruminal fermentation, and serum glucose and insulin of early-weaned steers. J. Anim. Sci. 81:843-855.

Smith, S. B., and J. D. Crouse. 1984. Relative contributions of acetate, lactate and glucose to lipogenesis in bovine intramuscular and subcutaneous adipose tissue. J. Nutr. 114:792-800.

Spitzer, J. C., D. G. Morrison, R. P. Wettemann, and L. C. Faulkner. 1995. Reproductive responses and calf birth and weaning weight as affected by body condition at parturition and postpartum weight gain in primiparous beef cows. J. Anim. Sci. $73: 1251-1257$.

Stalker, L. A., D. C. Adams, T. J. Klopfenstein, D. M. Feuz, and R. N. Funston. 2006. Effects of pre- and postpartum nutrition on reproduction in spring calving cows and calf feedlot performance. J. Anim. Sci. 84:2582-2589.

Stalker, L. A., L. A. Ciminski, D. C. Adams, T. J. Klopfenstein, and R. T. Clark. 2007. Effects of weaning date and prepartum protein supplementation on cow performance and calf growth. Rangel. Ecol. Manage. 60:578-587.

Underwood, K. R., J. F. Tong, J. M. Kimzey, P. L. Price, E. E. Grings, B. W. Hess, W. J. Means, and M. Du. 2008. Gestational nutrition affects growth and adipose tissue deposition in steers. Proc. Western Sec. Am. Soci. Anim. Sci. 59:29-32.

USDA-AMS. 2008a. Nebraska weekly feeder cattle auction summary. http://www.ams.usda.gov/mnreports/wh_ls795.txt Accessed July 22, 2008.

USDA-AMS. 2008b. 5 area weekly weighted average direct slaughter cattle. http://www.ams.usda.gov/mnreports/lm_ct150.txt Accessed July 22, 2008.

USDA-AMS. 2008c. National weekly direct slaughter cattle -Premiums and discounts. http://www.ams.usda.gov/mnreports/ lm_ct155.txt Accessed July 22, 2008.

Van Soest, P. J., J. B. Robertson, and B. A. Lewis. 1991. Methods for dietary fiber, neutral detergent fiber, and nonstarch polysaccharides in relation to animal nutrition. J. Dairy Sci. 74:3583-3597.

Wagner, J. J., K. S. Lusby, J. W. Oltjen, J. Rakestraw, R. P. Wettemann, and L. E. Walters. 1988. Carcass composition in mature cows: Estimation and effect of daily metabolizable energy requirements during winter. J. Anim. Sci. 66:603-612.

Waterman, R. C., E. E. Grings, T. W. Geary, A. J. Roberts, L. J. Alexander, and M. D. MacNeil. 2007. Influence of seasonal forage quality on glucose kinetics of young beef cows. J. Anim. Sci. 85:2582-2595. 